\title{
Securitisation across borders: the case of 'health security' cooperation in the European Union
}

\section{Louise Bengtsson \& Mark Rhinard}

To cite this article: Louise Bengtsson \& Mark Rhinard (2018): Securitisation across borders: the case of 'health security' cooperation in the European Union, West European Politics, DOI: 10.1080/01402382.2018.1510198

To link to this article: https://doi.org/10.1080/01402382.2018.1510198
(2) 2018 The Author(s). Published by Informa UK Limited, trading as Taylor \& Francis Group.

Published online: 09 Nov 2018.

Submit your article to this journal 4 View Crossmark data ¿ 


\title{
Securitisation across borders: the case of 'health security' cooperation in the European Union
}

\author{
Louise Bengtsson $^{\mathrm{a}}$ and Mark Rhinard ${ }^{\mathrm{b}}$ ii \\ ${ }^{a}$ Department of Economic History and International Relations, Stockholm University, \\ Stockholm, Sweden; 'bepartment of Economic History and International Relations, \\ Stockholm University and Swedish Institute of International Affairs, \\ Stockholm, Sweden
}

\begin{abstract}
Global health governance has increasingly become articulated and acted upon in ways that emphasise 'health security'. This article applies a collective securitisation approach to understand how a particular governance regime has evolved at the European level, one concerned with large-scale 'threats' to public health and societies at large. The analysis shows that alongside elitelevel securitisation moves, transnational professional networks and bureaucratic actors have also taken part both as securitising agents and audience, with outcomes reflected not only in policy change but also new EU-specific surveillance technologies, institutional structures, and information-sharing platforms. While these developments are partially interlinked with global trends, we show that the EU has gradually institutionalised its own approach to health security. This new status quo is enshrined in a legal framework and set of practices with an all-hazards approach targeting preparedness, early detection and containment of 'serious cross-border threats to health' of any origin - beyond infectious disease.
\end{abstract}

KEYWORDS Collective securitisation; public health; health security; European Union; critical security studies

The treatment of certain public health problems across the world as a matter of 'health security' took root in the 1990s. Starting with the framing of 'emerging infectious disease' as a threat to US national interests (King 2016), later coupled with a concern over biological and chemical weapons in the so-called Global War on Terror (Fidler and Gostin 2007; Kittelsen 2009; Rychnovská 2016), the securitisation of health has been explored via studies of the World Health Organization (WHO), the UN 
Security Council, as well as national health and security agendas (Davies 2008; Elbe 2010; Enemark 2009; Hanrieder and Kreuder-Sonnen 2014; Kamradt-Scott and McInnes 2012; Rushton 2011; Weir 2012).

In Europe, government health agencies are enmeshed not only in the WHO and other UN bodies but also within an increasingly institutionalised health security regime nested in the European Union. ${ }^{1}$ The EU has gradually carved out a direction for itself in a way that has received little attention from a securitisation perspective (for exceptions, see Kittelsen 2013 and Elbe et al. 2014 on pandemic influenza). In recent years, EU cooperation has developed from a focus on regular collection and sharing of national surveillance data on a number of listed diseases towards an increasingly dominant 'all-hazards' approach targeting 'serious crossborder threats to health'. For this purpose, EU-specific outputs such as threat-tracking tools and rapid alert networks have been developed and complemented with stronger capacities at the EU level - including the independent ability of the European Commission to proclaim a 'public health emergency', to collectively procure vaccines, and to strengthen preparedness for large-scale health crises across sectors (European Union 2013).

We argue here, with the help of a 'collective securitisation' analytical framework, that a variant of securitisation has taken place in EU public health cooperation. This securitisation is subtler than in its original Copenhagen School conception, in which existential threat construction and extraordinary measures serve as analytical currency (Buzan et al. 1998). Health security illustrates the transformation of political authority into a form of institutionalised exceptionalism, in which the EU has become endowed with a 'decisionist authority to define emergencies and guide political responses' not unlike other international organisations such as the WHO (Hanrieder and Kreuder-Sonnen 2014: 332). Our case reveals some particularities, however. Not one but several different precipitating events understood as 'health crises' have shaped securitisation. Further, our case points to the relevance of approaching the securitising agent/audience relation and question of 'policy outcomes' in a dynamic way, involving multiple actors and a focus on changes in terms of practices (C.A.S.E. Collective 2006).

The article proceeds as follows. We first reprise the collective securitisation approach, focusing on the steps set out in the framework. The empirical section then presents evidence of collective securitisation, showing how a series of precipitating events were progressively harnessed to a shift in discourses, agendas and practices. The conclusion draws out our key findings: namely, that developments are best understood by examining (i) sequential framings and responses to precipitating events; (ii) how 
new discourses and practices emerged through recursive interaction between lower-level bureaucratic actors, transnational professional networks and higher-level policy officials from both the European Commission and the member states; and (iii) how securitisation eventually became accepted and routinised within the EU setting.

\section{The collective securitisation approach}

The collective securitisation framework is laid out by Sperling and Webber (2018). We only note its most relevant aspects here as context for the analysis we undertake in the following sections. Collective securitisation challenges the assumption found in the original Copenhagen School (CS) framework, which privileged the nation-state as the referent object (Buzan et al. 1998: 24). The CS admittedly nuanced this assumption by developing the notion of societal security, with community identities as a possible referent object distinct from the state (Waever et al. 1993). 'Macro-securitisation', meanwhile, allowed for securitising moves between the state and system level (Buzan and Waever 2009). However, empirical focus remained largely on particular states as the unit of analysis and the CS neglected consideration of processes by which states collectively engage in securitisation around common concerns. ${ }^{2}$

To remedy this analytical blind spot, Haacke and Williams (2008) theorised how securitisation can take place within regional cooperation arrangements focusing on the African Union and the Association of South East Asian States. This version, however, underplayed what Sperling and Webber (2017: 28) refer to as the 'densely institutionalised security spaces' in which 'well developed rules and norms' shape threat considerations and in which supranational actors play important roles in securitisation processes. Making good that omission, collective securitisation as seen by Sperling and Webber (2018) adds an important insight on the role of the audience: how (representatives of) regional organisations can become securitising agents in their own right, with member states as the audience accepting or rejecting those efforts. In a move towards intersubjectivity - rather than speech act acceptance - Sperling and Webber (2018) theorise a 'recursive interaction' between securitising actor and receiving audience, with each influencing and shaping the other so 'as to blur the actor-audience distinction'.

Collective securitisation also proposes its own take on the importance of exceptional measures. In the CS approach, the outcome of securitisation is seen as an extraordinary state of affairs in which 'normal politics' is supplanted by the enabling of emergency measures (Buzan et al. 1998: 24-7). In collective security environments, argue Sperling and Webber 
(2018), this move may not be necessary to connote securitisation (for a related argument on health securitisation, see Hanrieder and KreuderSonnen 2014). Drawing on security governance literature, they argue that threat construction may be accepted and become institutionalised in policies, practices and logics which eventually become part of a new normality. International organisations may thus become empowered to take emergency measures as part of their normal politics, not as an exception to it. Following Floyd (2016), this leads to an assumption that a successful securitising move is one followed by some form of changed behaviour although these policy outcomes may be an adaptation of past practices as much as emergency or exceptional measures.

Proceeding from these assumptions, in this article we argue that the collective securitisation framework opens conceptual space for a more practice- and process-oriented view of securitisation in line with a general turn in securitisation studies that has been evident since the mid-2000s (C.A.S.E. Collective 2006; Guzzini 2011; Stritzel 2007). Especially in an EU context, focusing on securitisation moves by political elites from the member states or the European Commission reveals only part of the securitising process. As argued by Neal (2009: 351), attention to bureaucratic practices is particularly relevant since 'within the $\mathrm{EU},[\mathrm{m}] \mathrm{uch}$ of what is being done in the name of security is quiet, technical and unspectacular ... and just as much again does not declare itself to be in the name of security at all'. Van Munster's (2009: 6) study of securitisation of migration in the EU has emphasised the interactive effect of both politicians and bureaucratic actors, arguing that the political level often plays an important role in either 'authorizing, legitimizing, justifying, thwarting, dislocating or upsetting the enunciations of security professionals' (Van Munster 2009: 6). A similar position is taken by McInnes and Rushton (2013), who argue that multiple levels interact to shape the securitisation of health issues. With this approach, collective securitisation may be seen as a practice-based dynamic through which events are framed and responded to by a multitude of actors in a complex and ongoing process. These insights are used to complement the collective securitisation framework, to help explain the transformation of EU cooperation on infectious diseases into a regime and approach geared toward the pursuit of 'health security'.

\section{From cooperation on communicable disease to 'health security' in the EU}

Infectious disease cooperation in the EU cannot be analysed in isolation from its broader institutional and global setting (Davies 2008; Elbe 2010; Enemark 2009; Hanrieder and Kreuder-Sonnen 2014; Kamradt-Scott and 
McInnes 2012; Rushton 2011; Weir 2012). Kittelsen (2013: 118-20) argues that the securitisation of health and consequent cooperation at the EU level has been driven by three influences: a context of emerging health crises (specifically pandemic influenza), peer examples of international cooperation aimed at protecting health security, and the status of health policy as a means to advance European integration more broadly.

On the first of these, one should bear in mind that securitisation at the EU level has occurred against a changing global context, and new priorities both nationally and globally (Jacobson 2012). Our analysis includes these broader trends where relevant. We focus mainly on the intricate dynamics at the EU level, however, because we want to examine the plausibility of the collective securitisation framework in this specific, highly institutionalised context. We emphasise that with significant legislative developments since 2013, a particular health security regime has developed at the EU level with capacities for surveillance, risk assessment and coordination. We argue that this development, nested in the European Commission (hereafter, 'Commission') and the European Centre for Disease Prevention and Control (ECDC) represents a form of securitisation by which a new overarching vocabulary and set of priorities has taken shape.

As for the second influence, a number of international bodies and networks interact with and shape EU action on infectious diseases. This includes most prominently the WHO. That body's International Health Regulations (IHR) adopted in 2005 place a legal obligation upon its members to respond to any event of potential international public health concern' and to report the occurrence irrespective of its cause and origin (Santos-O'Connor et al. 2014: 46). The IHR, in turn, has been instrumental in the formation of the Global Health Security Agenda, a partnership of over 64 states launched in 2014 involving the WHO, the UN Food and Agriculture Organization, and the Office for Disaster Risk Reduction, as well as Interpol, the Economic Community of West African States and the EU. Other developments include the Global Health Security Initiative (GHSI) established after the 2001 anthrax attacks under US-Canadian leadership (which includes the European Commission as a member) (Jacobson 2012). Combining national health authorities in Europe, along with international bodies and networks, the institutional landscape in which the EU operates is indeed crowded and fragmented (Elliott et al. 2012: 951; Greer and Kurzer 2013). Even the Council of Europe (a nonEU institution) has occasionally tapped into this institutional landscape as we shall see below, it took a role in contesting the securitisation of pandemic influenza (Flynn 2010). 
The third influence - the role of health in European integration - is best considered by reference to EU discourse and practices. To that we now turn, as part of our consideration of the steps in the collective securitisation process.

\section{The collective securitisation of health}

\section{Status quo security discourse and practice}

The first stage in the collective securitisation framework involves the assessment of a starting point, conceptualised as a status quo in the beginning of a cycle. In the case of the EU health security regime, this is a period in which EU cooperation on infectious diseases had emerged but had not yet been permeated with the logic and priorities of health security.

EU public health policies started to take shape in 1992 when the member states agreed under Article 129 of the Treaty on European Union (TEU; now Article $168 \mathrm{TFEU}$ ) to 'Community action ... directed towards the prevention of diseases', 'the coordination of policies and programmes' in liaison with the Commission and the adoption by the Council of Commission proposals. This legal competence at the EU level formalised a number of previous, looser cooperation agreements on issues like cancer and HIV/AIDS (Kittelsen 2013). The Commission soon thereafter launched its 'Framework for Action in the Field of Public Health' (1993), which identified a list of issues for Community action including cancer, HIV/AIDS, health promotion-education-training, drug dependency, health monitoring, rare diseases, pollution-related diseases, and accidents and injuries. The Amsterdam Treaty, signed in 1997, codified this focus by stating that 'Community action shall complement national policies directed towards improving public health, preventing human illness and diseases, and obviating sources of danger to human health' (Article 152 EC). At this point, the EU's focus was still on the sharing of best practices around traditional public health data, research and the prevention of a limited set of known diseases (Steffen 2012). The larger shift toward the surveillance of global 'health threats' had not yet occurred (CastilloSalgado 2010).

Increasingly, however, a loose network of European epidemiologists coalesced, connecting national health authorities and overlapping with international networks (Jacobson 2012). While these networks emerged independently of the EU, they managed to convince Commission civil servants to fund a pilot platform through which national centres for communicable disease control could connect on a voluntary basis (Greer 2012). Through the so-called Charter Group, a range of disease-specific networks could thus expand their activities and facilitate information 
exchange, using the existing capacities of national agencies for surveillance in relation, for instance, to tuberculosis, HIV/AIDS and food-borne diseases. These nascent structures became part of a new European framework which, in collaboration with the Commission, led to the production of a pan-European bulletin (Eurosurveillance) and a high-level training programme in epidemiology and communicable disease control: the European Programme for Intervention Epidemiology Training - EPIET (Jacobson 2012; Liverani and Coker 2012). These developments were later formalised in a 1998 legislative act (European Union 1998) through which the networks were incorporated into EU institutions. Most importantly, this resulted in the establishment of an EU-level Early Warning and Response System (EWRS) for infectious diseases which connected national health authorities for the purposes of information sharing and response coordination. Member states were thus obliged to report infectious disease outbreaks where an occurrence was likely to affect other states in the Union (Santos-O'Connor et al. 2014).

By the end of the 1990s, EU health policies had by these routes developed a particular emphasis on infectious diseases. It should be noted, however, that national authorities remained the main focal points of activity (Elliott et al. 2012), and that the logic of the developing EU regime was still focused mainly on the collection of notifiable infectious disease data according to common sets of indicators. The vocabulary and priorities of 'health security' had yet to take root as a modus operandi, even if, through the 1990s, global agendas began to shift. That said, the framing of 'emerging infectious disease' in developing countries as a threat to Western interests (King 2016; Maclean 2008), together with newly established platforms like the Global Public Health Intelligence Network (GPHIN), ${ }^{3}$ prompted new perspectives in international health cooperation (Davies 2008; Weir and Mykhalovskiy 2010). The WHO, of which EU member states are part, would consolidate these developments via its approach to pursuing 'Global Health Security' (Davies 2008).

In short, infectious disease prevention and control emerged as one of the most salient areas of health cooperation at the EU level towards the end of the 1990s. This initial, non-securitised status quo, used as a baseline in our analysis, was influenced and intermeshed with broader trends and global networks. The latter, via a European grouping of epidemiologists, was able to harness funding opportunities and eventually become institutionalised at the EU level. The first elements of an institutional framework thus crystallised, with a particular focus on the sharing of public health data and an early warning system for infectious disease outbreaks of cross-border potential. These networked forms of cooperation still lacked the emphasis on looming health crises, anticipatory 
governance and the all-hazards approach to cross-border threats to health that would later emerge and characterise the EU health security regime.

\section{The precipitating event}

The collective securitisation framework stipulates the importance of a 'precipitating event or a set of cascading events of gravity sufficient to disrupt [the] status quo and prompt a perception by the securitising actor (and its audience) that the qualitative character of the internal or external security environment has worsened' (Sperling and Webber 2018). In our case, not one but several events must be considered of such significance. Below we present evidence of these precipitating events, all of major importance as health crises that fundamentally shook the EU institutions, dating from the mid-1990s to the late 2000s.

Previously, scholars have argued that the HIV/AIDS epidemic provided a 'template' for EU health cooperation (Steffen 2012) and that the Severe Acute Respiratory Syndrome (SARS) outbreak in 2003 proved a seminal moment for EU health security cooperation (Greer 2012; Hanrieder and Kreuder-Sonnen 2014). While not disputing those arguments, we find a more direct connection with the transformation towards health security in the 1996 discovery of beef tainted by Bovine Spongiform Encephalopathy (BSE), or 'Mad Cow' disease, which is commonly cited as the reason for the establishment of the EU's mandate in public health (Santos-O'Connor et al. 2014). The uncoordinated response, and the panic that spread as a result, threatened to severely damage the legitimacy of European institutions and member state governments in the eyes of citizens, who started to doubt the capacity of the EU to protect their health and safety. Even the internal market was seen to be at risk of dissolution (Grönvall 2001). The event was thus seen as a significant political and economic crisis prompting urgent attention towards health and consumer safety issues at the European level. A reorganisation of the Commission took place as a result. A new, separate department for health and consumer policy (Directorate General for Public Health and Consumer Protection or DG SANCO, later renamed DG SANTE) was established in 1999 (Kittelsen 2013: 105; Rhinard 2010: 196). This would later become the institutional home for - and bureaucratic driver of growing capacities of the EU health security regime.

The next precipitating event was the 11 September 2001 (9/11) attacks

- and more precisely the detection of lethal anthrax spores in Washington, DC in the days that followed.

As is well-documented, this discovery spurred fears among politicians in the US and Europe that pathogens might be deliberately spread and 
used as weapons of terror (Fidler and Gostin 2007; Kittelsen 2009; Maclean 2008; Rychnovská 2016). Concerns led to a global surge in spending on 'biodefence' and political attention to combat 'bioterrorism', which subsequently became a major focus of the US-led GHSI that was launched as a G7 + Mexico platform (Davies 2008; Elbe 2010; Fidler and Gostin 2007). Significantly, the European Commission was invited to join and the EU's first Commissioner for Health, David Byrne, attended the inaugural GHSI meeting in 2001 (European Commission 2003: 6).

The 2003 outbreak of SARS, too, played a formative role in the sequential process by which the status quo in EU health cooperation was altered. The outbreak in Asia brought further fears of the disruptive potential of health crises reaching Europe, and the EU response to this event was crucial for collective securitisation. As SARS was likened to the devastating 'Spanish flu' of 1918-1920, a direct effect of the response was the decision to swiftly establish the ECDC in Stockholm in 2004 (European Union 2004; Greer 2012).

With the ECDC in place and a shift in discourse and practices regarding the proliferation of infectious diseases underway, two additional precipitating events further entrenched developments: the H5N1 'avian influenza' virus in 2005 and the H1N1 'swine flu' virus in 2009. The avian influenza emerged in Southeast Asia, where it caused not only the death of hundreds of millions of birds, but also significant economic loss. While this outbreak never caused a human pandemic, it spurred panic as dead birds were found at European borders and EU member states resorted to the frantic procurement of antiviral medications (Elbe et al. 2014). The avian influenza, together with the SARS crisis, also had an important indirect effect on the EU through the resulting revisions of the WHO International Health Regulations that entered into force in 2007 (SantosO’Connor et al. 2014).

When the H1N1 'swine flu' virus in 2009 transferred to humans and reached pandemic proportions, preparedness and pharmaceutical stockpiling was again elevated to the top of the EU agenda - and led to considerable cooperation problems (Elbe et al. 2014; Taylor 2012). Although the symptoms of the H1N1 pandemic turned out to be milder than initially expected, which caused some public resistance to the largely securitised response (see below), this moment of resistance did not stop the gradual entrenchment of a new health security regime at EU level. As we shall see below, the above described precipitating events were interpreted and acted upon in a process of collective securitisation that involved, above all, supranational agents of the European Commission, expert communities and national leaders eventually shifting the status quo towards the new shared discourses and priorities of health security. 


\section{The securitising move}

According to collective securitisation, securitising moves take place in an interactive way with audience acceptance. However, the exact nature of this interaction in practice is blurred. Securitising moves do not originate only in a supranational institution such as the Commission but emerge also from member state officials or mixed networks. Securitising moves, further, are not the sole province of high-level officials making public statements. Securitising moves, which as we show can take the form of securitising practices, can also be carried out by expert communities and/ or bureaucratic officials. Nor is the language of an 'existential threat' a necessary condition for identifying a securitising move, either; it may be a subtler process based on the specialities of a specific context. And in some areas, the resort to language or expressions linked to 'emergency', 'urgency' and 'risk' can lead to new behaviours (Hanrieder and KreuderSonnen 2014).

The health scare related to the BSE outbreak and its spread to human beings was driven, for the most part, by an initial media outcry. National leaders resorted to protectionism while the Commission found itself facing considerable criticism. But over time, the Commission managed to frame the problem as a threat from and to transnational food chains (Grönvall 2001). It brought attention to the importance of preserving public confidence in public health institutions, and it highlighted the role of threats originating in other sectors - such as the food chain and the agricultural sector - as potential sources of 'public health crises' (Maclean 2008; Santos-O'Connor et al. 2014).

The $9 / 11$ and anthrax attacks in the US prompted a further shift in discourse towards collective securitisation. Shortly after those events, EU leaders met in Ghent, Belgium to take part in a classic securitising move. The member states swiftly declared their intention, at the highest political level, to 'combat terrorism in every form, throughout the world'. Regarding the public health implications of the attacks in particular, they responded by urging the launch of a programme on biological and chemical agent attacks:

The European Council asks the Council and the Commission to prepare a programme to improve cooperation between the Member States on the evaluation of risks, alerts and intervention, the storage of such means, and in the field of research. The programme should cover the detection and identification of infectious and toxic agents as well as the prevention and treatment of chemical and biological attacks. The appointment of a European coordinator for civil protection measures will be part of the programme. (European Council 2001: 4) 
The call of the so-called Ghent Conclusions to finalise this programme were followed up at the European Council in Laeken in December 2001, and carried over into European Council meetings in 2002, when its scope was expanded to nuclear and radiological terrorism (European Council 2002). With the adoption of a programme of action in November 2002, 'CBRN' threats (a new notion linking chemical, biological, radiological and nuclear incidents) entered the vocabulary of the EU and was placed at the top of the political agenda:

[C]hemical, biological, radiological and nuclear (CBRN) terrorism is a threat to international peace and security. The fight against terrorism requires a comprehensive approach comprising political, economic, diplomatic, military and legal means and should also include the preparation for as well as the prevention and limitation of the consequences of an attack. (Council of the European Union 2002: 3)

The precipitating event of $9 / 11$ thus prompted a broad-brush securitising move at the political level, which had the effect of linking together various kinds of hazards under the new vocabulary of CBRN, with the idea of large-scale health crises in mind. A big impetus in this regard was undoubtedly the US move of coupling such events under the GHSI that was set up following the attacks in 2001. As noted above, the European Commission was also a member and attended the GHSI's meetings from the start. Notably, pandemic influenza was later added to the GHSI's tasks, further reinforcing the idea of 'health threats' as an all-hazards form of security concern. The Commission's DG SANCO was an active part in further articulating this securitising move, notably through its Communication setting out the so-called Health Security Programme in 2003 (European Commission 2003). Through this action, the idea of deliberate and nondeliberate health hazards were coupled together and linked to other sectors such as civil protection and intelligence cooperation (Kittelsen 2009).

These securitising moves were followed by other, less high-profile, securitising dynamics evident in the role of two different professional expert networks. These two networks responded to the BSE and 9/11 events in different ways. The Charter Group, comprising high-ranking national epidemiologists, was initially satisfied with the status quo, in which EU cooperation was a matter of disease-specific surveillance networks of which national health authorities remained the focal points (Giesecke and Weinberg 1998; see also Liverani and Coker 2012). A separate professional group of microbiologists, however, used a different set of arguments, issuing threat-based warnings published in prestigious scientific journals such as Nature (Tibayrenc 1997). They argued that the EU's 'loose' approach to networked infectious disease cooperation could not cope with large-scale shocks such as major food-borne outbreaks or 
'bioterrorism', and advocated the creation of a powerful EU public health agency (Tibayrenc 1997, 2001). In this debate, Commission officials initially sided with the epidemiologists and the non-centralised approach, while the European Parliament supported the establishment of the European agency proposed by the microbiologists (Greer 2012).

The SARS outbreak in 2003 changed this dynamic, as it generated unprecedented political will to widen and deepen cooperation along the lines of the new priority of health security. This boosted the community of microbiologists and enabled their previous securitisation moves to shape the political agenda. This time, the Commission adopted the argument and vocabulary of securitisation, and announced its decision to set up a dedicated EU agency, the ECDC (Greer 2012).

Additional events followed which provided the European Commission, and the ECDC in particular, with opportunities to further respond in line with the shared concern for health security. The 'avian influenza' virus (2005) and the 'swine flu' virus (2009) led to excessive stockpiling of pharmaceutical countermeasures at member state level and propelled both the Commission and later the newly established ECDC in their drive to frame certain events as matters of health security (Elbe et al. 2014; Kittelsen 2013).

\section{Audience response}

As set out in the collective securitisation framework, securitising moves take place in a recursive manner entailing audience acceptance. This dynamic of inter-subjectively shared securitisation moves and acceptance is consistent with approaches to securitisation as an iterative process (Guzzini 2011). The recursive relationship between securitising agent and audience has been noted by Kittelsen (2013: 121) in her study of the securitisation of pandemic influenza in the EU and more generally in studies of 'securitisation as practice' in the EU context (Bigo 2013; Neal 2009; Van Munster 2009).

Our analysis confirms precisely this recursive relationship but with a twist. In the Sperling and Webber (2018) version of collective securitisation, the securitising actor is taken to be a supranational EU, while the audience is understood mainly as composed of the member states. But a blurring of actor and audience is also possible. As an example, Commission officials were responsible for the language which has framed health issues and have acted as the accepting audience which then uses that language to justify policy responses. Thus, the Commission supported the language of 'CBRN threats' and one of its main responses to the 9/11 attacks was to promote a Health Security Programme from which was 
established the Health Security Committee (Rhinard 2009). Following the SARS outbreak, meanwhile, the Commission argued in favour of a centralised expert agency to provide expertise and assist coordination in relation to health threats. Here, a key influence was felt by the public pronouncements of Commissioner David Byrne and the preparatory work of Fernand Sauer, the European Commission's Director for Public Health who had recently been involved in setting up the European Medicines Agency in London (Greer 2012). Further complicating the actor-audience distinction is the role played by networks of health experts. Ostensibly, these highly qualified and well-organised groups might be seen as the audience of securitisation. However, as noted above, they also have a significant influence on policy given their role in lobbying and opinion forming. The European network of epidemiologists, for instance, first played the role of defendant of the policy status quo, later that of audience to be won over after the SARS outbreak, and then active formulators of 'health security' following avian influenza and swine flu once the ECDC was established. In fact, the ECDC would not only take over the management of existing disease networks under the Charter Group, but also hire many prominent epidemiologists from national health authorities.

At the political level, too, it is difficult to pinpoint the difference between a securitising actor and an accepting audience. As is well known in Brussels policy circles, the Commission works closely with the Council's General Secretariat and the Presidency of the Council in drafting both legislation and Council Conclusions for the member states. As an example, the Commission seems to have swiftly made an inventory of existing capacities following 9/11, in order to help formulate and refine the EU's response. There is evidence to suggest that it was through this inventory that EU officials began institutionalising the notion of 'health security', which made further headway with the adoption by the Council and Parliament of the Health Security Programme noted above (Kittelsen 2013).

This description suggests a rather 'easy' audience acceptance of securitising moves, which much literature on securitisation suggests is not always the case (see for instance Balzacq 2005). Here our research revealed some pockets of resistance to securitisation, evident initially on the part of the Charter Group and later, albeit to a limited extent, by experts working with 'traditional' disease surveillance at the ECDC. The most articulated public resistance to securitisation was directed at the EU institutions and member state governments in relation to their handling of the 2009 H1N1 'swine flu' outbreak. As part of these controversies, the Social Health and Family Affairs Committee of the Parliamentary 
Assembly of the Council of Europe, in a rather scathing critique, expressed its alarm at

the way in which the H1N1 influenza pandemic has been handled, not only by the World Health Organization (WHO), but also by the competent health authorities at the level of the European Union and at national level. It is particularly troubled by some of the consequences of decisions taken and advice given leading to distortion of priorities of public health services across Europe, waste of large sums of public money, and also unjustified scares and fears about health risks faced by the European public at large. (Flynn 2010)

Additional complaints were levelled at the subterranean manner in which assessments were made and recommendations issued (Hanrieder and Kreuder-Sonnen 2014). Thus, not all members of the audience interpreted the securitising moves in the field of European health governance in similar fashion (see McInnes and Rushton 2013).

That said, for the most part, audience acceptance was clear that 'health threats' had become a matter of European security, requiring 'all-hazards' surveillance and new kinds of response and preparedness. The Council, Commission and ECDC officials as well as professional networks served at different times both as securitising agents and audience in a recursive securitisation process. Consistent with collective securitisation, our analysis shows that a supranational institution (the Commission, along with the ECDC acting as an expert agency and locus of new outcomes) contributed to securitisation by articulating the nature of the threat and the appropriate response. This latter, in turn, has implications for policy.

\section{Policy outputs}

Following the securitisation move and acceptance between the securitising agent and audience, analytical attention in the collective securitisation approach turns to policy outputs and implementation. As argued in the introduction, limiting analysis to the production of formal policies misses much of what happens at the EU level in terms of security practices; other, less visible bureaucratic forms of output matter just as much (Neal 2009; Van Munster 2009). This is especially true in public health policies, where at the EU level the functions of coordination and support entail a focus on expertise, technologies for surveillance, and risk assessment. In this light, attention must go beyond the simple adoption of new policies. Apart from a new main legal framework adopted in 2013 (see below), which enshrines, strengthens and institutionalises the vocabulary and priorities of new EU health security regime, our case also shows the importance of outputs such as EU-funded Information Technology (IT) tools, 
new forms of risk assessment, and the establishment of new institutions, networks and research priorities.

Following the BSE crisis, the Commission took an active role in promoting a wide array of initiatives and ideas that were formative for EU cooperation on public health as well as food and consumer safety. The new DG SANCO became the dedicated location for cooperation and support on public health issues at the EU level, soon after to be bolstered by the European Food Safety Authority (EFSA) established in 2002 in Parma. The new focus on monitoring, rapid alert systems and risk assessments related to the food chain has become a central feature of these new institutional structures (Boin et al. 2014: 422).

The outputs following $9 / 11$ and the anthrax attacks, meanwhile, related largely to the Council's call to action on biological and CBRN threats (Council of the European Union 2002). The structures then set up through the newly established Health Security Programme established a link between bioterrorism and public health, mirroring the approach taken by the US-led GHSI initiative. That link meant the Commission and the Council could build on existing EU structures such as the Civil Protection Mechanism and the EWRS for infectious disease (Kittelsen 2013: 145). These structures, in turn, became linked to a new rapid alert system for 'CBRN threats': the Rapid Alert System for Biological and Chemical Threats (RAS-BICHAT) (Boin et al. 2014). In related developments, in 2002 health security received financial attention in the Commission's Multiannual Financial Programme (European Commission 2002) and (reflecting the addition of pandemic influenza to the scope of the GHSI) a Council request from 2004 led to an expansion of the EU Health Security Committee's mandate, to include pandemic preparedness and response coordination (Kittelsen 2013: 182).

Additional institutional innovations following the SARS outbreak in 2003 included most importantly the emergence of the ECDC. This EU agency was to become an important hub not only for scientific expertise but also for the use and refinement of new events-based surveillance and so-called 'epidemic intelligence'. The latter, part of a widespread trend in public health governance, utilises global surveillance tools and platforms to analyse informal sources such as online articles and social media in order to better detect outbreaks before they reach the stage of official case reports (Brownstein et al. 2008; Paquet et al. 2006; Roberts and Elbe 2017). The ECDC is also the main actor involved in managing the EUwide EWRS, an early warning system accessible to EU institutions and member states. Since its establishment in 1998, the EWRS's remit has expanded to cover health threats no matter where their origin (Bengtsson et al. 2018). In 2005, the ECDC created its own Emergency Operations 
Centre to coordinate surveillance, risk assessment and assistance to member states during crises.

Other important initiatives reside with the Commission. Outputs include those developed by the Joint Research Centre such as the EU Medical Information System (MediSys), and threat-tracking tools (SantosO'Connor et al. 2014), and the Health Emergency Operations Facility (HEOF) set up by the Commission's DG SANCO to provide a technology-supported facility to assist coordination by national officials (Brem and Dubois 2010). Its secure facilities in Luxembourg have developed common decision procedures, information-sharing protocols and closed systems for communication during health crises.

A significant wave of outputs followed the securitisation efforts associated with the 'swine flu' outbreak in 2009. Together with the need to implement the WHO's International Health Regulations, weaknesses in the EU's response prompted new legislation to replace the 1998 framework. Introducing the possibility of collective vaccine procurement and boosting the mandate of the Health Security Committee, the legislation formalised the category of 'serious cross-border threats to health', encompassing a variety of sources such as natural disasters and heat waves to risks in the food chain as well as 'CBRN' and major outbreaks of infectious disease (European Union 2013). Moreover, and rather extraordinarily, the Commission obtained authority to proclaim a situation of 'public health emergency' towards the general public (European Union 2013; see also Hanrieder and Kreuder-Sonnen 2014). The relevant 2013 decision of the Council and European Parliament stipulates that a Commission proclamation can be used to trigger a fast-track approval process in EU pharmaceutical legislation for the development of new vaccines or other medical countermeasures (European Union 2013).

Finally, another kind of policy output has been an increasing focus at the EU level on preparedness support aimed at sharing best practice between national pandemic preparedness plans. In particular, a new focus on 'generic' preparedness has arisen within the ECDC, which aims to support member states to prepare not just health systems but whole societies for major 'crossborder health threats' of any origin (Santos-O'Connor et al. 2014).

In short, repeated and recursive securitising moves following a series of events articulated as 'health threats' has driven new policy outputs. These have included new tasks, new surveillance methods, new methodologies and new institutions. These outputs have laid the foundations for a new set of priorities and a vocabulary of 'health security' at the EU level. While these developments cannot be separated from similar trends in global health governance, they suggest the institutionalisation of a specific EU health security regime with its own particularities. 


\section{The new status quo}

Once securitisation has taken place, and outputs embed and reflect that move, the collective securitisation approach posits that matters become routinised and are manifested in a new strategic vocabulary, agenda and set of practices. In this final stage of the model, the cycle is completed in that this new status quo becomes institutionalised.

For our case, we have already outlined above how a range of events was interpreted and acted upon in ways which laid the foundations for 'health security' as a new vocabulary and set of routinised practices in EU institutions and member state networks. This new collective understanding based on the imagery of looming 'serious cross-border threats to health' intersects and coexists with 'traditional' approaches to infectious disease control at both the EU and national levels (Santos-O'Connor et al. 2014). However, there are several novelties in nature and scope, reflecting the EU's own particular take on 'health security'. This approach is now firmly embedded in the 2013 legal framework on 'serious cross-border threats to health' (Council of the European Union 2013).

Specifically, the new status quo is not only concerned with infectious diseases per se. 'Serious cross-border threats to health' is a novel and expansive category understood to encompass food-borne disease, deliberate or accidental release of dangerous substances ('CBRN', 'bioterrorism', 'biosafety'), large-scale infectious disease outbreaks (typically influenzalike pandemics), acute health implications of environmental origin, and even hitherto 'unknown' threats to human health (European Union 2013). The new securitised status quo thus implies a shift towards an 'all-hazards' approach and 'societal security', more in line with the growing capacities of the EU as a 'crisis manager' (Boin et al. 2013) and a proliferation of EU-level early warning systems (Bengtsson et al. 2018). The new status quo is also reflected in new kinds of priorities enabled by 'epidemic intelligence', 'events-based' monitoring and rapid risk assessments within the ECDC. These practices have entailed a focus on anticipatory governance and algorithmic tools for the detection and containment of threatening 'events', alongside 'traditional' case reporting of infectious disease (Roberts and Elbe 2017). The focus on surveillance, rapid risk assessment and coordination of response to a 'serious cross-border threat to health' is reflected in the Commission's bureaucratic structures and the ECDC, which can switch to special crisis modes when its leadership designates an outbreak as sufficiently serious. On such occasions, special operational structures are set in place in the ECDC and in DG SANTE (Bengtsson et al. forthcoming).

A final aspect of the new status quo worth noting is the stronger focus on preparedness for large-scale crises, which goes beyond disease-specific 
preparedness of public health systems. Coordination and support of member state resilience extends to so-called 'generic preparedness' for major health crises of any origin that may affect a range of societal functions. This move towards societal security and support of crisis management suggests 'serious cross-border health threats' are regarded as something qualitatively different from the mere prevalence of infectious disease. All these aspects reflect and consolidate the new vocabulary and priorities of 'health security' at the EU level.

\section{Conclusion}

This article applied a collective securitisation approach to understand the way in which parts of EU public health policy - more specifically, infectious disease control - have come to be reframed and expanded under the new vocabulary and priorities of 'health security'. More specifically, we have cast light on crisis-driven processes from the late 1990s, indicating the emergence of a new, shared understanding through the entry point of urgency, crisis and a generic notion of 'serious cross-border threats to health'. Closely intertwined with global developments, this regime coexists with but is also partly removed from 'traditional' approaches to infectious disease control, in that 'events', no matter what their origin (biological, chemical, nuclear, environmental or unknown), can be designated as threats to human health and eventually also to European societies. The need to prepare for such crises thus arises as a more looming concern, beyond preparedness for handling particular diseases outbreaks.

In short, the collective securitisation approach used in this special issue takes us some way toward understanding the transformation of health governance at the level of the EU institutions. Yet our case also points to some particularities. For instance, it reveals the possibility that not only one but several subsequent precipitating events or external shocks may shape collective securitisation. In our case, a series of events - first a food crisis ('mad cow disease'), followed by a biological attack (the anthrax letters after $9 / 11$ in the US) and three highly contagious outbreaks (SARS, avian influenza and 'swine flu') - shaped responses in a way that explains much about how and what kind of securitisation took place. Our case also points to a second important finding when it comes to the nature of the 'securitising move' and 'audience response'. We found that not only member states and the Commission, but also transnational professional networks and bureaucratic actors, alternatively played the role of securitising agent and audience, in a way which blurs the distinction between the two. Occasional opposition to securitisation was also found, but failed to halt the process. Finally, our findings suggest that policy outputs per se 
are a crude measure of manifested securitisation. Other broader indicators of change, including development of new routines, practices, technologies and networks may prove just as consequential. This finding mirrors previous studies of securitisation in the EU, which argue that securitisation need not be associated only with existential threat construction and exceptional measures (Kittelsen 2009; Neal 2009: 351; Van Munster 2009). Future research on collective securitisation could thus benefit from more practice- and process-oriented approaches as demonstrated here.

\section{Notes}

1. Throughout this article, 'EU' is used generally to mean the EU institutions (the Council, the Commission, the European Parliament and the European Council) and agencies.

2. It should be noted that Buzan and Waever (2009) did consider the 'scale' question and suggested that securitisation may very well contain a transnational element. This aspect was not thoroughly explored in their work, however.

3. The GPHIN surveillance platform was the first of its kind, in that it enabled early detection of outbreaks before they were reported by health authorities, through the use of web-scanning methodologies.

\section{Acknowledgements}

We are grateful for research assistance provided by Sarah Backman, a PhD candidate in International Relations at Stockholm University, as well as three anonymous reviewers for West European Politics who helped improve the quality of this article.

\section{Disclosure statement}

No potential conflict of interest was reported by the author(s).

\section{Notes on contributors}

Louise Bengtsson is a $\mathrm{PhD}$ fellow in International Relations at Stockholm University, specialising in critical security studies and the politics of global health governance.

Mark Rhinard is Professor of International Relations in the Department of Economic History and International Relations at Stockholm University, where he specialises in international cooperation on complex threats. He is also a Senior Research Fellow at the Swedish Institute of International Affairs and Senior Advisor at the European Policy Centre, Brussels. He is the author (with Raphael Bossong) of Theorising Internal Security Cooperation in the European Union (Oxford University Press, 2016); (with Neill Nugent) The European Commission (Palgrave, 2015); (with Arjen Boin and Magnus Ekengren) The European Union 
as Crisis Manager (Cambridge University Press, 2013); and Framing Europe: The Policy Shaping Strategies of the European Commission (Nijhoff, 2010).

\section{ORCID}

Mark Rhinard (D) http://orcid.org/0000-0002-1903-4257

\section{References}

Balzacq, Thierry (2005). 'The Three Faces of Securitization: Political Agency, Audience and Context', European Journal of International Relations, 11:2, 171-201.

Bengtsson, Louise, Stefan Borg and Mark Rhinard (2018). 'European Security and Early Warning Systems: from Risks to Threats in the European Union's Health Security Sector', European Security, 27:1, 20-40.

Bengtsson, Louise, Stefan Borg and Mark Rhinard. (forthcoming). 'Assembling European Health Security: Epidemic Intelligence and the Hunt for CrossBorder Health Threats', Security Dialogue.

Bigo, Didier (2013). 'Analysing Transnational Professionals of (In)security in Europe', in Niilo Kauppi and Mikael Rask Madsen (eds.), Transnational Power Elites: The New Professionals of Governance, Law and Security. Abingdon and New York: Routledge, 114-130.

Boin, Arjen, Madalina Busuioc, and Martijn Groenleer (2014). 'Building European Union Capacity to Manage Transboundary Crises: Network or Leadagency Model?', Regulation and Governance, 8:4, 418-36.

Boin, Arjen, Magnus Ekengren and Mark Rhinard (2013). The European Union as Crisis Manager: Patterns and Prospects. Cambridge: Cambridge University Press.

Boin, Arjen, Magnus Ekengren and Mark Rhinard (2014). Making Sense of SenseMaking: The EU's Role in Collecting, Analysing and Disseminating Information in Times of Crisis. Stockholm: Swedish National Defence College, Acta B Series No. 44.

Brem, Stefan and Stéphane Dubois (2010). 'Different Perceptions, Similiar Reactions: Biopreparedness in the European Union', in Peter Katona, John P. Sullivan, and Michael D. Intriligator (eds.), Global Biosecurity: Threats and Responses. Abingdon and New York: Routledge, 137-156.

Brownstein, John S, Clark C. Freifeld, Ben Y. Reis and Kenneth D. Mandl (2008). 'Surveillance sans frontières: Internet-based Emerging Infectious Disease Intelligence and the HealthMap Project', PLoS Medicine, 5:7, 1019-024.

Buzan, Barry and Ole Waever (2009). 'Macrosecuritization and Security Constellations: Reconsidering Scale in Securitization Theory', Review of International Studies, 35:2, 253-76.

Buzan, Barry, Ole Waever and Jaap de Wilde (1998). Security: A New Framework for Analysis. Boulder and London: Lynne Rienner Publishers.

Castillo-Salgado, Carlos (2010). 'Trends and Directions of Global Public Health Surveillance', Epidemiologic Reviews, 32:1, 93-109.

C.A.S.E. Collective (2006). 'Critical Approaches to Security in Europe: A Networked Manifesto’, Security Dialogue, 37:4, 443-487.

Council of the European Union (2002). Adoption of the Programme to Improve Cooperation in the European Union for Preventing and Limiting the 
Consequences of Chemical, Biological, Radiological, or Nuclear Terrorist Threats, 14627/02 (Brussels, 21 November).

Council of the European Union (2013). 'Decision (1082/2013/EU) of the European Parliament and of the Council on serious cross-border threats to health and repealing Decision No 2119/98/EC', Brussels, 22 October, Official Journal of the European Union, L 293/1-15.

Davies, Sara. E (2008). 'Securitizing Infectious Diseases', International Affairs, 35 : 2, 186-206.

Elbe, Stefan (2010). Security and Global Health. Cambridge, UK: Polity Press.

Elbe, Stefan, Anne Roemer-Mahler and Christopher Long (2014). 'Securing Circulation Pharmaceutically: Antiviral Stockpiling and Pandemic preparedness in the European Union', Security Dialogue, 45:5, 440-57.

Elliott, Heather A, David K, Jones and Scott L. Greer (2012). 'Mapping Communicable Disease Control in the European Union', Journal of Health Politics, Policy and Law, 37:6, 935-54.

Enemark, Christian (2009). 'Is Pandemic Flu a Security Threat?', Survival, 51:1, 191-14.

European Commission (2002). Communication from the Commission to the Council and the European Parliament. Civil Protection on Progress made in Implementing the Programme for Preparedness for Possible Emergencies, COM (2002) 302 final, Brussels, 11 June.

European Commission (2003). Communication from the Commission to the Council and the European Parliament. Civil Protection on Cooperation in the European Union on Preparedness and Response to Biological and Chemical Agent Attacks [Health Security], COM (2003) 320 final, Brussels, 2 June.

European Council (2001). Declaration by the Heads of State or Government of the European Union and the President of the European Commission. Follow up to the September 11 Attacks and the Fight against Terrorism, Press Release, Brussels, 19 October.

European Council (2002). Programme of the Council and the Commission of 20 December 2002 to Improve Cooperation in the European Union for Preventing and Limiting the Consequences of Chemical, Biological, Radiological or Nuclear Terrorist Threats (2002 CBRN Programme), Brussels: Council Document 14627/ 2002

European Union (1998). Decision No 2119/98/EC of the European Parliament and of the Council of 24 September 1998 Setting up a Network for the Epidemiological Surveillance and Control of Communicable Diseases in the Community, OJ L 268/1, Brussels, 3 October.

European Union (2004). Regulation of the European Parliament and of the Council (851/2004) Establishing a European Centre for Disease Prevention and Control, Brussels, 21 April.

European Union (2013). Decision (1082/2013/EU) of the European Parliament and of the Council on Serious Cross-Border Threats to Health and Repealing Decision No 2119/98/EC, Brussels, 22 October.

Fidler, David and Lawrence O. Gostin (2007). Biosecurity in the Global Age: Biological Weapons, Public Health, and the Rule of Law. Stanford, CA: Stanford University Press.

Floyd, Rita (2016). 'Extraordinary or Ordinary Emergency Measures: What and Who Defines the "Success" of Securitization?', Cambridge Review of International Affairs, 29:2, 677-94. 
Flynn, Paul (Rapportuer) (2010). 'The Handling of the H1N1 Pandemic: More Transparency Needed', Draft Resolution of the Parliamentary Assembly of the Council of Europe, available at: https://assembly.coe.int/CommitteeDocs/2010/ 20100604_H1N1pandemic_e.pdf (accessed 20 June 2018).

Giesecke, Johan, and Julius Weinberg (1998). 'Correspondence: A European Centre for Infectious Disease?', The Lancet, 352, 1308.

Greer, Scott. L (2012). 'The European Centre for Disease Prevention and Control: Hub or Hollow Core?', Journal of Health Politics, Policy and Law, 37:6, 1001-036.

Greer, Scott L., and Paulette Kurzer (2013). European Union Public Health Policy: Regional and Global Trends. Abingdon and New York: Routledge.

Grönvall, J. (2001). 'Mad Cow Disease: the Role of Experts and European Crisis Management', in Uriel Rosenthal, R. Arjen Boin, and Louise K. Comfort (eds.), Managing Crises: Threats, Dilemmas, Opportunities. Springfield, IL: Charles C. Thomas.

Guzzini, Stefano (2011). 'Securitization as a Causal Mechanism', Security Dialogue, 42:4-5, 329-41.

Haacke, Jürgen, and Paul D. Williams (2008). 'Regional Arrangements, Securitization, and Transnational Security Challenges: The African Union and the Association of Southeast Asian Nations Compared', Security Studies, 17:4, 775-809.

Hanrieder, Tine, and Christian Kreuder-Sonnen (2014). 'WHO Decides on the Exception? Securitization and Emergency Governance in Global Health' Security Dialogue, 45:4, 331-48.

Jacobson, P. D. (2012). 'The Role of Networks in the European Union Public Health Experience', Journal of Health Politics, Policy and Law, 37:6, 1049-55.

Kamradt-Scott, Adam, and Colin McInnes (2012). 'The Securitization of Pandemic Influenza: Framing, Security and Public Policy', Global Public Health, 7:S2, S95-S110.

King, Nicholas B (2016). 'Security, Disease, Commerce: Ideologies of Postcolonial Global Health', Social Studies of Science, 32:5, 763-89.

Kittelsen, Sonja (2009). 'Conceptualizing Biorisk: Dread Risk and the Threat of Bioterrorism in Europe', Security Dialogue, 40:1, 51-71.

Kittelsen, Sonja (2013). 'The EU and the Securitization of Pandemic Influenza', PhD thesis, Aberystwyth University, September 2013, available at: http://cadair. aber.ac.uk/dspace/handle/2160/13193 (accessed 20 June 2018).

Liverani, M., and Coker, R (2012). 'Protecting Europe from Diseases: From the International Sanitary Conferences to the ECDC', Journal of Health Politics, Policy and Law, 37:6, 915-34.

Maclean, Sandra J (2008). 'Microbes, Mad Cows and Militaries: Exploring the Links between Health and Security', Security Dialogue, 39:5, 475-94.

McInnes, Colin and Simon Rushton (2013). 'HIV/AIDS and Securitization Theory', European Journal of International Relations, 19:1, 115-138.

Neal, Andrew (2009). 'Securitization and Risk at the EU Border: The Origins of FRONTEX', Journal of Common Market Studies, 47:2, 333-56.

Paquet, Christoph, Denis Coulombier, Reinhard Kaiser and Massimo Ciotti (2006). 'Epidemic Intelligence: A New Framework for Strengthening Disease Surveillance in Europe', Euro Surveillance: Bulletin Européen Sur Les Maladies Transmissibles = European Communicable Disease Bulletin, 11:12, 212-4. available at: [CrossRef][10.2807/esm.11.12.00665-en] https://www.eurosurveillance. org/content/10.2807/esm.11.12.00665-en (accessed 20 June 2018). 
Rhinard, Mark (2009). 'European European Centres for Disease Control', Review of Policy Research, 26:4, 439-455.

Rhinard, Mark (2010). Framing Europe: The Policy Shaping Strategies of the European Commission. Boston, MA: Brill/Republic of Letters.

Roberts, Stephen L., and Stefan Elbe (2017). 'Catching the Flu: Syndromic Surveillance, Algorithmic Governmentality and Global Health Security', Security Dialogue, 48:1, 46-62.

Rushton, Simon (2011). 'Global Health Security: Security for Whom? Security from What?', Political Studies, 59:4, 779-96.

Rychnovská, Dagmar (2016). 'Governing Dual-Use Knowledge: From the Politics of Responsible Science to the Ethicalization of Security', Security Dialogue, 47: $4,310-28$.

Santos-O'Connor, Francisco, Jukka Pukkila and Carmen Varela-Santos (2014). 'The Health Security Framework in Europe', in Bernd Rechel and Martin McKee (eds.), Facets of Public Health in Europe, New York, NY: Open University Press.

Sperling, James and Mark Webber (2017). 'NATO and the Ukraine Crisis: Collective Securitization', European Journal of Internatuional Security, 2:1 19-46.

Sperling, James and Mark Webber (2018). 'The European Union: Security Governance and Collective Securitization', West European Politics. doi:10.1080/ 01402382.2018 .1510193

Steffen, Monika (2012). 'The Europeanization of Public Health: How Does It Work? The Seminal Role of the AIDS Case', Journal of Health Politics, Policy and Law, 37:6, 1057-89.

Stritzel, Holger (2007). 'Towards A Theory of Securitization: Copenhagen and Beyond', European Journal of International Relations, 13:3, 357-83.

Taylor, R. C. R. (2012). 'Public Health in a Transnational Context: Explaining Europe's Role', Journal of Health Politics, Policy and Law, 37:6, 1111-20.

Tibayrenc, Michel (1997). 'European Centres for Disease Prevention and Control', Nature, 389:6650, 433.

Tibayrenc, Michel (2001). 'A European Centre to Respond to Threats of Bioterrorism and Major Epidemics', Bulletin of the World Health Organization, 79:12, 1094.

Van Munster, Rens (2009). Securitizing Immigration: The Politics of Risk in the EU. Basingstoke: Palgrave Macmillan.

Waever, Ole, Barry Buzan, Morten Kelstrup and Pierre Lemaitre (1993), Identity, Migration and the New Security Agenda in Europe. New York, NY: St Martins Press.

Weir, Lorna (2012). 'A Genealogy of Global Health Security', International Political Sociology, 6:3, 322-325.

Weir, Lorna and Eric Mykhalovskiy. (2010). Global Public Health Vigilance: Creating a World on Alert. Abingdon and New York: Routledge. 